\title{
補足と文献案内
}

\section{川口正美 严重大学工学部}

ここでは, 紙面の都合上揭載できなかった日本人研究 者による高分子の散逸構造に関するいくつかの研究例 を，編集委員の一人として紹介する.

散逸構造を高分子のモルフォロジーの 1 つとしてと らえ，その制御が Q. Tran-Cong らによって行われてい る. 彼らは, 下限臨界共溶温度を有するポリスチレン誘 導体／ポリビニルメチルエーテル (PS/PVME) ブレンド について，さまざまな条件下において PS 鎖上のアント ラセンの二量化反応によって光架橋し, ブレンド系の不

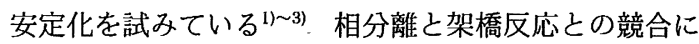
よって,さまざまな散逸構造が発現した ${ }^{11}$. 光架橋でブレ ンドの相分離を誘起すると，長波長のゆらぎが抑制さ れ, 相分離の後期過程で構造成長が停止しながら, 秩序 化することがわかった. ま また，直線偏光で架橋すると， 偏光の方向 (E) に平行するゆらぎが選択的に抑制され, 相分離の初期過程では (E) とほぼ平行なラメラ状のモル フォロジーが得られだ).

熊木らは，上限臨界共溶温度を有するポリスチレン／ ポリブタジェンブレンドのジオクチルフタレート溶液 が，その共存温度より約 $20^{\circ} \mathrm{C}$ 上の均一な一相領域にお いて，わずか $2^{\circ} \mathrm{C}$ の温度勾配をつけるだけで相分離する ことを見いだしだ)。この現象は，温度勾配 (熱拡散) が 濃度勾配をひき起こす結果，すなわち Soret 効果による ことがわかった. 今後，これが傾斜（濃度勾配）高分子 材料の構築に応用されることを期待したい.

高分子材料の成形・加工時によく見られる自励振動現 象は高分子の散逸構造の発現に起因している. 戸田はポ リエチレンテレフタレート (PET) 非晶フィルムの延伸 時に観察されるネッキング（くびれ）が伝播する際の自 励振動 5 や直鎖状ポリエチレン $(\mathrm{PE})$ 溶融体のダイ押し 出し時に観察されるメルトフラクチャーでの自励振動 等 ${ }^{6)}$ について，実験と数值計算を併用して研究を行って いる，PET の場合，ガラス状態における変形で，PEの 場合, 高分子融体の流動であるので, 両者の変形過程は まったく異なっている。それにあかかわらず，それぞれ の自励振動におけるダイナミクスにいくつかの類似点の
あることを明らかにした意義は大きい，また，この知見 は高分子材料の塑性変形による破壊の研究に役立つはず である.

分子あるいは粒子の自己組織化による材料の構築に関 する研究が精力的に行われている. 雲母表面をポリスチ レン (PS)の希薄なベンゼン溶液で洗い流し，それを乾 燥した後に原子間力顕微鏡で観察すると, PS の会合体 の規則的に配列したメゾスコピックなパターンが，Kar thaus らによって見つけられた7).これは, 溶媒の蒸発過 程に生ずるフィンガーがトリガーになっているあのと考 えられる。

散逸構造は高分子研究者にとって馴染みの薄い分野で あるために，取っ付きにくいところはあるが，それに関 する現象は高分子の世界にあ多く潜んでいるはずであ る.この特集号に挙げたいくつかの研究は，最初から散 逸構造を目的とした研究ではなかったと聞く．新しい学 問の創設が期待されるこの分野でのさらなる展開を期待 したい.

\section{文献}

1) Q. Tran-Cong, A. Harada: Phys. Rev. Lett., 76, 1162 (1996)

2) Q. Tran-Cong, T. Ohta, O. Urakawa: Phys. Rev., 56, R59 (1997)

3) K. Kataoka, O. Urakawa, Q. Tran-Cong: Polym. Prep. Jpn., 46, 614 (1997)

4) J. Kumaki, T. Hashimoto, S. Granick: Phys. Rev. Lett., 77, 1990 (1996)

5) A. Toda: Polymer, 34, 2306 and 3638 (1993)

6) A. Toda: Polym. Prep. Jpn., 44, 3433 (1995)

7) O. Karthaus, J. Ijiro, M. Shimomura: Chem. Lett., 821 (1996), O. Karthaus, L. Grasjo, M. Shimomura: Polym. Prep. Jpn., 46, 895 (1997)

\section{[散逸構造に関する成書］}

- 蔵本由紀, 川崎恭治, 山田道夫, 甲斐昌一, 篠本 泓：パターン形成, 朝倉書店 (1991)

・沢田康次：非平衡系の秩序と乱れ，朝倉書店 (1993)

・森肇，蔵本由紀：散逸構造とカオス, 岩波書店 (1994) 